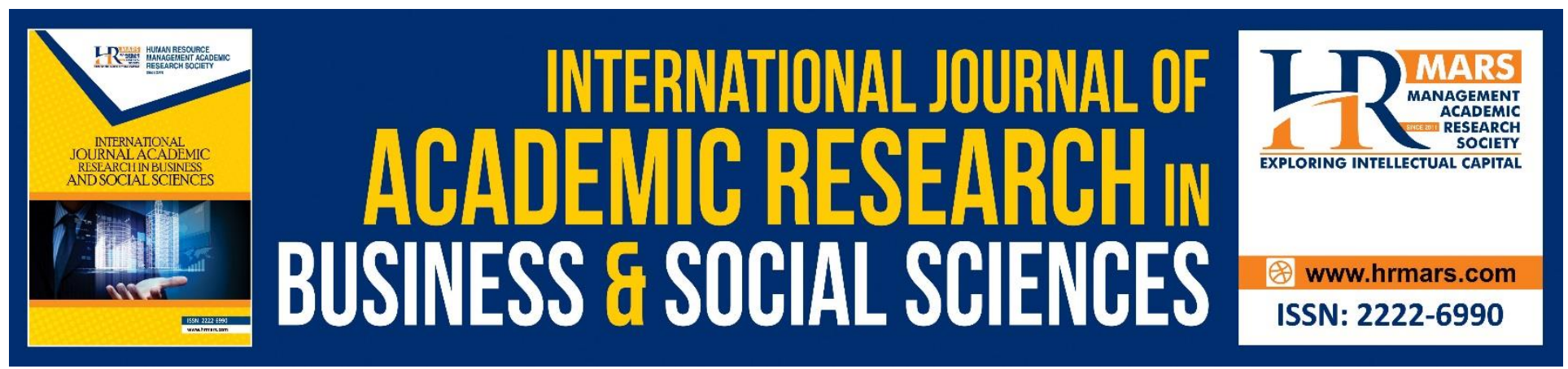

\title{
Loss Aversion Bias in Working Capital Management and Performance of Small and Medium Enterprises (SMEs): The perspectives of Ghanaian SME Managers
}

Jeff Lamptey, Asri Bin Marsidi

To Link this Article: http://dx.doi.org/10.6007/IJARBSS/v10-i5/7180

DOI:10.6007/IJARBSS/v10-i5/7180

Received: 02 March 2020, Revised: 12 April 2020, Accepted: 25 April 2020

Published Online: 07 May 2020

In-Text Citation: (Lamptey \& Marsidi, 2020)

To Cite this Article: Lamptey, J., \& Marsidi, A. Bin. (2020). Loss Aversion Bias in Working Capital Management and Performance of Small and Medium Enterprises (SMEs): The perspectives of Ghanaian SME Managers. International Journal of Academic Research in Business and Social Sciences, 10(5), 127-141.

Copyright: (C) 2020 The Author(s)

Published by Human Resource Management Academic Research Society (www.hrmars.com)

This article is published under the Creative Commons Attribution (CC BY 4.0) license. Anyone may reproduce, distribute, translate and create derivative works of this article (for both commercial and non-commercial purposes), subject to full attribution to the original publication and authors. The full terms of this license may be seen

at: http://creativecommons.org/licences/by/4.0/legalcode

Vol. 10, No. 5, 2020, Pg. 127 - 141

http://hrmars.com/index.php/pages/detail/IJARBSS

JOURNAL HOMEPAGE

Full Terms \& Conditions of access and use can be found at http://hrmars.com/index.php/pages/detail/publication-ethics 


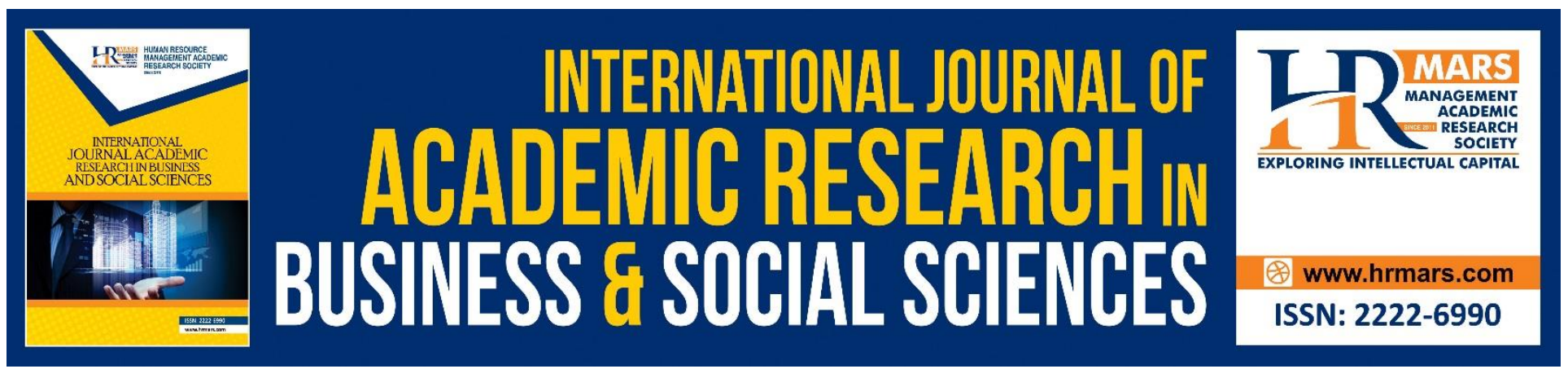

\title{
Loss Aversion Bias in Working Capital Management and Performance of Small and Medium Enterprises (SMEs): The perspectives of Ghanaian SME Managers
}

\author{
Jeff Lamptey, Asri Bin Marsidi \\ Faculty of Economics and Business, Universiti of Malaysia Sarawak \\ Email: jefflampt@gmail.com, maasri@unimas.my
}

\begin{abstract}
We examine Loss aversion bias in working capital management and performance of Small and medium-sized enterprises (SMEs) in Accra, Ghana. Our study adopts a qualitative case study approach and in-depth interviews to obtain data from thirty-five (35) Owner-managers. This research shows that SME managers(owners) are loss aversion as they evaluate financial outcomes by thinking about loss and profits and use profits in most financial decision thereby prone to fear of loss. Moreover, SMEs managers (owners) subjected to enormous fear tend to be highly loss averse over loss (uncertain gain) and risk averse. While managers(owners) with less fear are low loss averse over profits and risking seeking. By implication, low loss averse SME managers(owners) tend to perform better than highly loss averse managers who underinvest in working capital in inventory, resulting in decreased profit margins. Thus, we conclude SMEs manager's loss aversion matters in working capital management and performance.
\end{abstract}

Keywords: Loss Aversion, Ghanaian SMEs Working Capital Management, Performance.

\section{Introduction}

Small and medium enterprises (SMEs) are expected to manage working capital to enhance performance. Managers are required to follow the standard working capital practices for optimum decision. However, they hardly apply theories but rather use subjective methods of working capital decision (Filbeck and Lee, 2000; Bandara and Rathnasiri, 2016). This subjective decision can expose managers to several biases, including loss aversion (Tversky and Kahneman, 1974) which is one of less studied managerial biases compared to overconfident bias. Following the theoretical evidence of Tversky and Kahneman (1974), much of the literature in loss aversion comes from investors (Rephael et al. 2012; Bouteska and Regaieg, 2018 and fund managers (Bodnarruk, 2016) show that loss aversion bias highly influence financial decisions. However, there is still limited knowledge about loss aversion behaviors of managers(owners) of SMEs, given their managerial role and as key financier. 
Loss aversion is popular concept for decision making under risk. It posits that people have a tendency of avoiding loss of a fortune than making gain of same amount. People generally believe that the psychological pain of loss is steeper than the psychological gain of same magnitude (Kahneman and Tversky 1984; Rostami and Dehaghani, 2015). Thus, profit or returns can enable individuals avoid the regret of loss and pains(Shiller,1998). For this reason, loss averse investors, for example, prefer certain gains and uncertain loss. Such investors believe that if they do not incur loss on investment then they will make profit on investment which distort the risk and return profile of their portfolio.

SMEs face a lot of uncertainty in financial management for optimal solution (Filbeck and Lee, 2000). This uncertainty appears relevant to Ghanaian SME while making working capital and performance decision. Since the operations of SMEs are less formalised, most firms consider mangers experiences as a useful framework for optimum working capital decision (Agyei-Mensah, 2012; Hamza et al., 2015; Donkor, 2015). While managers evaluate decision outcomes, they are much concern about loss and profit, not risk and return; and they want profit that maximise investment to enhance firm growth. But, considering that both loss and profit can occur due to uncertainty and can impact on manager emotions, firm's growth and personal welfare; however, we lack knowledge of manager's behaviors and how that influence working capital management in this situation. Nevertheless, we assume that managers, in most cases, want to realise gains like other investors. Therefore, the purpose of this paper is

- To identify loss aversion behaviors of SME managers.

- To influence of loss aversion behavioral biases of SMEs management on working capital management and performance.

\section{Literature Review and Development of proposition. Loss Aversion}

Researchers have shown that people who are loss averse generally assess financial outcome in terms loss and gains when faced with decision under risk. Kahneman and Tversky's (1979) were the first to establish that individual, including investors exhibit loss aversion bias while evaluating payoffs of their investment. Odean (1998) finds that a loss averse investors tend to sell good investment quickly to make gains, but on hold bad assets for long period in expectation of prices increase before trading their stocks. Similarly, Mahina et al. (2017) confirm the loss aversion behaviors of Rwanda investors and explain that the fear and anxiety of loss induces such investors to trade good investment early to avoid depression and regret. Investors loss aversion results in risk seeking behaviors when losses loom large and risk averse when making gains (Cherono et al. 2017; Gal and Rucker, 2018). Moreover, loser strategy portfolio produced higher excess market returns with increased holding period while winner strategy portfolios yielded lower excess market returns with increased holding period (Hsieh and Hodnett, 2011).

Similar researchers have found ample evidence for loss aversion of professionals (Pope and Schweitzer, 2011; Locke and Mann, 2005). In particular, Lock and Mann (2005) observe that although professional traders are loss averse due to increased holding period for bad portfolios than good ones, the evidence does not suggest decrease in returns. Moreover, highly loss averse fund managers produce lower returns on mutual funds investment than fund managers with low aversion. At the same time, higher managerial loss-aversion results in lower performance (Bodnarruk, 2016). 
INTERNATIONAL JOURNAL OF ACADEMIC RESEARCH IN BUSINESS AND SOCIAL SCIENCES

Vol. 10, No. 5, May, 2020, E-ISSN: 2222-6990 @ 2020 HRMARS

\section{Working Capital Management and Performance Decision}

Literature in working capital management mostly suggest that SMEs lower investment in current assets (e.g. inventory, accounts receivable) in order to create higher value and avoid tie up capital (Konak and Güner 2016; Lamptey et al., 2017). Similar studies show that SMEs are better off with higher working capital investment in order to increase sales, sustain operations (Deelof,2003; Blinder and Maccini, 1991). Nonetheless, many scholars believe that market forces, industry and economic factors and firm characteristics largely influence the level of working capital investment (Sogorb-Mira 2005; Ban os-Caballero et al., 2010). In terms of performance, it has been established, among many factors, that working capital management directly affects SME profitability. Thus, most researchers believe that decreased working capital investment enhances SME performance than increased working capital investment. Despite the facts small business managers make most working capital decision based on their experience, their perspectives have not been included. Based on these, we formulate the following propositions that:

1. Highly loss averse SME manager(owners) underinvestment in working capital decrease firm performance.

2. Low Loss aversion SME managers(owners) overinvestment in working capital increases performance.

\section{Loss Aversion (Prospect Theory)}

The loss aversion is a prominent feature in the Prospect Theory of decision making under risk and uncertainty pioneered by Kahneman and Tversky (1979). Loss aversion holds that individuals do not like loss and thus evaluate outcome of financial decision in term loss and do not consider the value gain and loss equally. As It is believed that the weight of loss surpasses the weight of the gain, indicating that psychological loss is more painful than the psychological gain of equivalent value. In this line, Individual investor under loss aversion uses profits in decision rather loss in order to avoid the emotional and psychological pains and regret (Kahneman and Tversky,1979 Shiller, 1998).As such individual investors assume or feel that if loss is not realised for investment in the financial market , then profits will be earned on investment (Bouteska and Regaieg, 2018).With this mind the investor wants to obtain profits from the investment by quickly selling good assets to avoid decrease in stock price but maintain and refuse to trade non performing security below the purchase price. Considering the fact that loss is a classic example of regret of aversion, there is the possibility that investors will feel the pains of regret for loss of investment and wish to avoid such pains of regrets (Shiller, 1998).

In this regards, several studies have used the concept of loss aversion to explain investors loss aversion behaviors. A case in point is endowment effect as described by (Kahneman et al. 1980) as the tendency for investors to value an object more highly when it is in their possession than they would value the same object if they did not already possess it. Furthermore, disposition effect configures investors as individual who are more sensitive to decrease level of investment than to increases (Benartzi \& Thaler, 1993) that is why loss averse investors quickly sell winners to maximize immediate profits and holds on worthless security anticipating increase in stock price before to selling (Odean,1998). This behavior makes loss averse investors risking seeking when realizing loss and risk averse when realizing gains. In addition, the behavior of loss aversion is linked to sunk cost fallacy when an investor avoids alternative viable projects over less profitable project because of having 
INTERNATIONAL JOURNAL OF ACADEMIC RESEARCH IN BUSINESS AND SOCIAL SCIENCES

Vol. 10, No. 5, May, 2020, E-ISSN: 2222-6990 @ 2020 HRMARS

invested substantially in later project (Kelly, 2004). Other studies have found evidence of loss aversion bias in marketing, law political science (Lizzeri and Yariv, 2014; Alesina and Passarelli, 2017). However, the implication and explanations of loss aversion in the working capital management decision is unknown.

\section{Methodology of Research and Research Design}

This study adopted qualitative research procedures to gain insight into the nature of loss aversion behaviors of SME managers (Domegan and Fleming, 2007). We reviewed loss aversion being the central issue requiring exploration for in-depth understanding because of paucity of knowledge (Birkinshaw et al. 2011). Considering the nature of loss aversion, we adhered to the advice of Strauss and Corbin,1998) who explained that "qualitative methods can be used to obtain the intricate details about phenomena such as feelings, thought, processes, and emotions that are difficult to extract or learn about through more conventional methods".

In terms of research strategy, we used single case as described by these authors (Yin, 1994; Merriam, 1988; Stake, 2000) as the best choice (Yin, 2003). A single case involves the study of one particular phenomena or thing or a single group of people (Yin, 2003) which provides in-depth understanding of subject (Dyer and Wilkins, 1991). This method assumes that exploring a single case study can "develop in-depth description and analysis of cases (Siggelkow, 2007; Creswell, 2018) and also create better theory" (Dyer \& Wilkins, 1991). Dyer and Wilkins (1991) contended that single case studies are better than multiple cases in terms of details and theorizing. This offers the researcher opportunity to query existing theoretical association and explore new relationship that requires a more critical or careful examination of the phenomenon.

\section{Target Participants and Sample Selection}

Our participants are managers (owners) of small and medium enterprises in Accra. We primarily chose them because of the nature of research questions and objectives of the study. This study uses purposive sampling and snow balling method as they are suitable for the study context and research questions (Palys, 2008). We recruited managers based certain criteria: managerial experience, availability, readiness and willing to participate share experiences, ability to communicate in language and local dialects, and communicate experiences and opinions and others (Spradley, 1979; cited in Etikan et al. 2016). This study anticipated that this sampling technique provided us the opportunity to obtain the diverse information from participants.

Our initial recruitment process begun after faculty approved the research. We personally contacted fifteen (15) participants (managers) through telephone and recommended to them to contact their peers, which we contacted later. Tentatively, we spoke to fifty-five (55) SME managers from Trading and manufacturing sector in Accra. In our second stage of the recruitment, after participants with the requisite qualification (e.g., three years of managerial experience in working capital management and above 25 years have been selected,) we emailed explanatory letters and consent form to participants (45) for confirmation, and only 40 responded. Later some participants decline to participate in the study and others too were dropped due lack of knowledge of the subject matter. Our final participants of thirty-five managers were determined based on saturation points during the interviews, possessing different demographic background shown in Table 1. 
INTERNATIONAL JOURNAL OF ACADEMIC RESEARCH IN BUSINESS AND SOCIAL SCIENCES Vol. 10, No. 5, May, 2020, E-ISSN: 2222-6990 @ 2020 HRMARS

\section{Table 1: Social demographic of Participants}

\begin{tabular}{ll}
\hline Participant & Number \\
\hline Age & 08 \\
$25-40$ & 20 \\
$41-50$ & 05 \\
$51-60$ & 02 \\
$61-$ and above & \\
Gender & 20 \\
Male & 15 \\
Female & \\
Education & 06 \\
Secondary & 05 \\
Diploma & 12 \\
Graduate & 08 \\
Professional & 07 \\
Master & \\
Managerial Experience(years) & \\
$3-5$ & 05 \\
$6-10$ & 09 \\
$11-15$ & 13 \\
$16-20$ & 06 \\
21 and above & 02 \\
Industry & \\
Trading & \\
Manufacturing & 12 \\
\hline
\end{tabular}

\section{Data Collection and Instrument}

Data were obtained through semi structured interviews, which has been described by Fontana and Frey $(2000 ; 645)$ to be "one of the most powerful way in which we try to understand our fellow human being". Telephone interview was used because it is a valid means of collecting qualitative data (Cachia and Millward,2011; Glogowska et al. 2011, Trier-Bieniek, 2012 and Vogl, 2013). This data collection instrument assumes that the use of telephone interviews in this study offers a great deal of convenience just like face to face- to- face interview (Deakin and Wake,2014). Cachia and Millard, 2011) argue that telephone interviews provide maximum privacy and comfort to participants to engage in lengthy conversation. It also offers the researcher opportunity to reach participants who hardly can be contacted personally due to business commitments (Fenig et al. 1993). These flexibilities stimulate the interest of participants due to time constraint, less demanding and overall method motivated managers to participate actively in the interviews (Cachia and Millward, 2011). The interviews focused on loss aversion behaviors in working capital management and performance guided by the interview protocols which was developed based on theory and empirical evidence. The use of the in-depth interview helped us identified actual behaviors of managers (William et al., 2015) through the opening ended conversion styles, probing, clarification, reminders 
INTERNATIONAL JOURNAL OF ACADEMIC RESEARCH IN BUSINESS AND SOCIAL SCIENCES

Vol. 10, No. 5, May, 2020, E-ISSN: 2222-6990 @ 2020 HRMARS

and quick recap (Shelden et al.2010; Burke and Miller, 2001; Glogowska et al. 2011). On average, each interview lasted between one hours to one hour- thirty minutes. Interviews were recorded, transcribed and then analyzed. Interview transcript and summary report were emailed to the managers for validation of the accuracy of their responses and positive feedbacks were received.

\section{Data Analysis}

The data analysis begun by identifying segment or patterns, that is, unit of data which is a potential finding or part of the answer to the research questions. Merriam (2009) explained that the unit of data can be any meaningfully a word or group or words used by the participants(managers) describe their feelings, behavior or occurrence. To identify these patterns in analyzing the data, we used thematic analysis which enabled the us to identify loss aversion behaviors of SMEs Managers and working capital management and performance decision.

In search for main categories or themes, the interview transcripts were thoroughly read for familiarsation and to make meaning of the data which ensured that participants responses on loss aversion and adjustment behavior and influence on working capital management performance have been properly captured, transcribed and understood meanings of the data. Next, the data were coded by making notes and comments that were potentially relevant to the research questions (Merriam ,2009). We used theoretical coding process which helped us to address specific research and each segment of data that was relevant was coded that capture exact word of participants, concept from literature or researcher words which potentially related to research question. Because we did have preset codes the open coding process was used to search for initial codes. All codes were entered into NVivo 12 Pro Computer software. In order to stay focused on loss aversion behaviors, we then reviewed and modified the initial individual theme identified into final themes being fear of loss as loss averse behavior of managers and their influence: overinvestment or underinvestment in working capital and increase or decrease in performance being the final themes, the main findings which gives more clarity on the descriptive accounts of SMEs managers behaviors in working capital and performance in our concept development map in Figure 1.

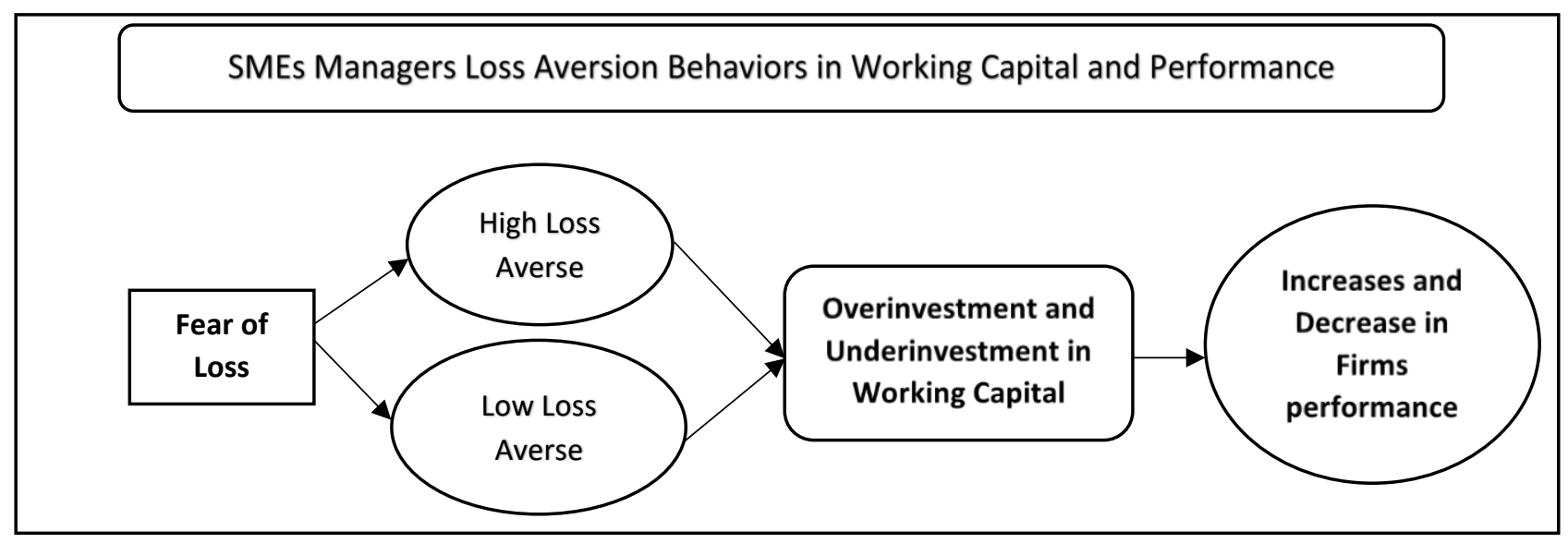

Figure 1: Concept mapping of influence of loss aversion in working capital and performance

\section{Confirmability of Findings}


INTERNATIONAL JOURNAL OF ACADEMIC RESEARCH IN BUSINESS AND SOCIAL SCIENCES

Vol. 10, No. 5, May, 2020, E-ISSN: 2222-6990 @ 2020 HRMARS

We confirmed our findings through member checks (Lincoln and Guba, 1985; Creswell, 2003) and respondent validation (Bloor, 1978; Lincoln and Guba, 1985). To obtain respondents validation, we presented interview transcripts to managers through email or contacted them by telephone to check for accuracy of data, and emergent themes, that is, if they saw their personal responses reflected in any or all the transcripts. In terms of member checks, we asked managers to comment on the exactness of their personal direct quotes and sought their consent to use their "verbatim quotes" in our article. All 35 participants confirmed that the summary of findings and verbatim quotes adequately and accurately represented their view on loss aversion behaviors in working capital management performance.

\section{Results}

\section{Loss Aversion Behaviors of SME Managers}

The interviews focused on loss aversion behaviors of participants and their influence on working capital and performance decision. We found that SMEs managers were loss averse. This finding emerged from one primary category fear of loss while their influence on working capital and performance resulted in overinvestment and underinvestment. In addition, within the fear of loss category, we constructed two subcategories which delineated SME manager's loss aversion.

The fear of loss generally indicated that participants dislike losing money or investment. This fear made managers to evaluate payoff in terms of loss and profits in making financial decision. Thus, SMEs managers wanted to be sure of their profit before making financial commitment. The perception of participants about fear of loss portrayed managers as either highly loss averse or low loss averse.

Highly loss averse managers tend to be too sensitive to loss of investment. This behavior occurred because participants have suffered loss or making losses which impact strongly on their moods (e.g. emotional and psychological state) and firm success and personal wellbeing. However, their experience and loss sentiments differs.

Participants 2, stated that: ..... "honestly, I feel extremely unhappy when I make loss. It makes me feel like I have just thrown my money into the drain and hurts me each time considering the impact on my business. This makes me uneasy that my next investment won't be secured" ..... Participants 1 also told us that: 'realising loss is a very painful moment and emotional battle. The loss affected business operations and my personal life very much. In fact, I am extremely careful now about my investment decision in order to avoid further loss"

We noted that such experiences led managers to be pessimistic or risk averse in their decision. As they doubted the efficiency of their decisions, security of their resources and outcome of next financial decision. In view of this,

participants 2, further stated that..... "I entertain a lot fears about safety of my capital and results of next decision......". In addition, participants 1, stated that........... "I'm very cautious and wondering if my decisions will bring positive results so I am bit reluctant to pursue other project that might be profitable....". Similarly, participant 12, was "guilty and dejected for making loss and worry about what kind of decision will yield the expected returns on my investment".... 
INTERNATIONAL JOURNAL OF ACADEMIC RESEARCH IN BUSINESS AND SOCIAL SCIENCES Vol. 10, No. 5, May, 2020, E-ISSN: 2222-6990 @ 2020 HRMARS

These experiences compelled participants to "employ protective or conservative mechanisms" as loss saving and emotional coping measures. By so doing, managers tend to minimise financial outlay or curtail investment level to meet their expected performance. These measures allowed managers avoid further loss, soothe their emotional pains and without aggravating their precarious condition until things improved. For this reason, participant1, for example, responded that:

"...... I reduced the level of investment in working capital inventory for some time to avoid further loss. This decision really helped, but my profit margin dropped. Likewise, participant 2, did not invest as before purposely to safeguard investment in inventory and firm collapse. Although, I realize profit, but not as much. Similar managers, included participant 12, "did not invest in working capital, inventory as previously because of the fears of insecurity of investment, emotional and psychological pains and regrets. And this affected my profit levels, nut I am okay for now". In addition, participant 7, stated that......" I am extremely careful and curtailed the level of investment inventory to protect my meager capital, but my profits level decreased" ......

Meanwhile, the fear of loss also portrayed managers as low loss aversion. As managers were less sensitive to loss when making profits that positively impacts on their moods, personal welfare and firm's prospects. Accordingly, participants want to realise more and more gains, believing to be certain. Based on these observations, participant 3 replied that:

"Making gains make me extremely happy and give me personal satisfaction. so I am sure I can make more profit no matter small the amount to enhance firm growth" .... Likewise, participant 11, also indicated that:" realising profit brings me joy, and gladden my heart and sustains my business too. Thus, I strongly believe I can increase my profit margins"... Furthermore, participant 8 revealed to us that "realizing profits boost my confident and challenge me to seek more returns for firm success and survival and my livelihood".......

Moreover, managers tend to be optimistic and risk seeking over gains. They overly trust in their ability to make good judgement and believe that will secure their investment to bring expected profits. $A$ classic case is participant 3 who stated that:

..... "my decision is very effective so long I am making profits and this makes me believe I can attain my business aspiration. I will invest more to make more profit". Similarly, participant 11, said that "I intend to invest substantially. I believe that my decision can positively enhance the firm's financial position and grow the business. Moreover "Realizing profit motivate participant 8 to pursue other investments, believing that the investment is secured and can increase profitability" ......

This finding suggest participants prefer increase working capital investment inventory to support firm growth and increase performance.

\section{Influence of SME Loss Aversion on Working Capital Management and Performance}

The influence of SME manager's loss aversion was overinvestment and underinvestment in working capital which also resulted in increase or decreases firm performance. In particular, highly Loss averse managers tend to curtail working capital investment inventory and thus decrease firm 
INTERNATIONAL JOURNAL OF ACADEMIC RESEARCH IN BUSINESS AND SOCIAL SCIENCES Vol. 10, No. 5, May, 2020, E-ISSN: 2222-6990 @ 2020 HRMARS

performance. This is the result of lose managers have suffered and the adverse impact on their wellbeing, business and emotional and psychological. These experiences induced manager's pessimism, distrust financial ability and doubt security of investment and outcome of desire performance. Consequently, managers may become inertia to pursue better alternative opportunity for better gains. With this mind, they tend to adopt conservative approach to protect working capital investment inventory in order to minimize pains of loss and regrets. For this reason,

Participants 2, stated that: "honestly, I feel extremely unhappy when I make loss. It makes me feel like I have just thrown my money into the drain and hurts me each time I think about it considering the impact on my business. This makes me uneasy that my next investment won't be secured. So I entertain a lot fears about safety of my capital and results of next decision. I reduced the level of investment for some time to avoid further loss. This decision really helped, but my profit margin dropped". Participants 1 also told us that: 'realising loss is a very painful moment and emotional battle. The loss affected business operations and my personal life very much. In fact, I am extremely careful about my investment decision in order to avoid further loss. And I'm wondering if my decisions will bring positive results so I am bit reluctant to pursue other project that might be profitable. So I did not invest as before purposely to safeguard investment and firm collapse. Although, I realise profit, but not as much. Similarly, participant 12, feel "guilty and dejected for making loss and worry about kind of decision that will yield the expected returns on my investment. I did not invest in working capital, inventory as previously because of the fears of insecurity of investment, emotional and psychological pains and regrets. And this affected my profits level, but I am okay for now. In addition, participant 7 stated that: I feel sad and anguish for making loss. This hurt me so my much and slow down business operation. It makes me skeptical that my business wont survival considering my meager capital I decide not to buy too stock for some time to protect my meager capital. Of course, this help but my profits level decreased"......

This means highly loss averse managers favors capital protection while making working capital decision and such firm may have less growth potential. This could be costly if managers succumb to too much fear without being innovative.

Overinvestment in working capital is influenced by low loss aversion. Low Loss averse managers tend to be optimistic and risk seeking when making profits and desire for more profits, resulting in increase working capital investment in inventory. This decision may imply that manager perceive gains to be certain and undertake riskier projects to facilitate firm growth and for more profits. This evidence is consistent with participants' comments. In particular, participant 3 asserted that:

"Making gains make me extremely happy and gives me personal satisfaction and I want to make more profit no matter small the amount to enhance firm growth. my decision is very effective so long I am making profits and this makes me believe I can attain my business aspiration. Thus I will invest more to make more profit". Likewise, participant 11, also indicated that" realising profits brings me joy, and gladden my heart and also sustains the business too. I strongly believe I can increase my profit margins and I intend to invest substantially. I believe that my decision can positively enhance the firm financial position and grow the business". Furthermore, participant 8 revealed to us 
INTERNATIONAL JOURNAL OF ACADEMIC RESEARCH IN BUSINESS AND SOCIAL SCIENCES

Vol. 10, No. 5, May, 2020, E-ISSN: 2222-6990 @ 2020 HRMARS

that "realizing profits boost my confident and challenge me to seek more returns for firm success and survival and my livelihood". I believe that I can make more profits by investing more in working capital, increasing my stock level."

By implication, low loss aversion managers prefer aggressive working capital management to improve firm performance and growth. This also mean such managers underestimates the capital loss associated with overinvestment in working capital

\section{Discussion and Conclusion}

Throughout the investigation of loss aversion behaviors of SMEs managers, the study revealed significant insights into how loss aversion behavior influence working capital and performance of Small and medium enterprises(SME). The participants we interviewed mentioned fear of loss as loss averse behaviors of SMEs managers. Participants specifically stated that they consider loss and gains as outcomes of their financial decision This suggests that mangers hate loss which is line with the assumptions of Kahneman and Tversky's (1979) and Barberis, et al 2001). For this reason, SMEs managers (owners) want to know amount profits to make in every financial decision before allocating financial resources. Participants responses suggest that if they did not make loss, then they will make profit.

Participants disclose to us that the fear of loss make them low loss averse or highly loss averse. This is because when managers realize loss they tend to be highly loss averse and become risk averse. Although this finding is similar to loss averse investors (Odean,1998, Cherono, et al. 2019), our findings suggest that loss averse SMEs managers tend to reduce working capital investment in inventory to prevent further loss due to the impact on their emotions, firm success and wellbeing. This finding also implies that such managers are too sensitive to loss and adopts conservative style in working capital management which similar to the evidence of Bodnarruk, (2016). However, when managers are making profits they are less sensitive to fear, implying they are low loss averse, optimistic and risking seeking. As a result, SME managers increase working capital by holding higher inventory to earn more profits to enhance firm growth and personally welfare. This finding contradicts with findings on loss aversion investors who reduce invest when making gains to avoid decrease in investment and regrets. In addition, this evidence show that managers prefer aggressive working capital investment decision similar to findings of Bodnarruk (2016), but opposite to the findings of these authors (Pais and Gama, 2015; Lamptey et al. 2017) which show that SME reduce working capital. Overall SME loss aversion distort traditional working capital management, showing that higher working capital investment improves firm performance.

\section{Conclusion and Contribution}

This paper investigated SME manager's (owners) loss aversion behaviors in working capital and performance decision. Thus, we conclude that SME managers are loss averse because they are prone to fear of loss and that influence working capital and performance decision. These managers rely on their fear of loss to increase working capital investment to maximize higher returns when they are realizing gains. This performance makes managers low averse and risking seeking believing that the gains are certain and thus commit more money to enhance firm growth and better their welfare. However, too much fear of loss makes managers highly averse when they realise loss and thus become pessimistic and risk averse. Moreover, the pessimistic and risk aversion behaviors of these 
managers results in decreased working capital investment in inventory in order to protect their meager capital from further loss.

The results imply that loss aversion matters in working capital and performance for SMEs managers. This paper argues that it is not enough to study working capital and performance of SMEs without their loss aversion biases that allow them to make decisions since most manager to do not apply theories. This study makes new contributions to loss aversion. First our article is the first to explore loss aversion behaviors in working capital and performance and thus we provide fresh empirical evidence on loss aversion on corporate managers and opens new research opportunity. In addition, we extend literature on loss aversion which mainly focus on investors. Furthermore, we make new contributions to body on knowledge based on the evidence of influence of loss aversion on working capital management and performance. We demonstrated that: (1) Loss aversion influence working capital management and performance. Thus (1a) higher loss aversion bias leads a decrease in working capital investment in inventory and performance. (1b) Lower loss aversion bias leads to an increase in working capital investment inventory and performance.

That means understanding of loss aversion behavioral bias in working capital management and performance of is essential to all SMEs managers if they want to maximise returns when face decision of uncertainty. More importantly, Ghanaian SMEs managers who believe that proper understanding and application of loss aversion can better enhance working capital management for desire performance rather than application of theories.

The implication of this result on SMEs managers and policy makers are several. This understanding helps policy makers and regulators of SMEs in Ghana and elsewhere to fashion necessary policies and programs to enhance SMEs financial management and practices. For example, Financial institution, banks, Microfinance institutions and other lending institutions can incorporate behavioral factors into credit assessment for SMEs loans by identifying and assessing the risk behaviors of loss averse managers to tailor credit needs in order to minimise the potential moral hazard. Second, it provides knowledge to managers how their behaviors can negatively or positively impact working capital decision and performance. This knowledge helps managers in evaluating inventory decisions to realize profits by adjusting inventory investment to suit operating activities and market demand. Where the expected return is highly unpredicted, the highly loss managers can have mitigated the risk seeking behaviors of low averse mangers by reducing investment in working capital. At the same time, lowly loss manger can enhance SME performance by increasing working capital when loss risk averse is more pronounced. Finally, we can fail to general our results so future researcher to examine effects on SMEs loss aversion on working capital.

\section{References}

Agyei-Mensah, B. (2012). Working Capital Management Practices of Small Firms in the Ashanti Region of Ghana. International Journal of Academic Research in Business and Social Sciences. 02(1),567-583.

Alesina, A., \& Passarelli, F. (2019). "Loss Aversion in Politics," American Journal of Political Science, 63(4), 936-947.

Bandara, R. M. S., \& Rathnasiri, U. A. H. A. (2016). The Working Capital Management Practices of Small and Medium Enterprises (SMEs) in Sri Lanka, ICME 2016, Faculty of Management and Finance, University of Ruhuna. 
INTERNATIONAL JOURNAL OF ACADEMIC RESEARCH IN BUSINESS AND SOCIAL SCIENCES

Vol. 10, No. 5, May, 2020, E-ISSN: 2222-6990 @ 2020 HRMARS

Baños-Caballero, S., García-Teruel, P. J., \& Martínez-Solano, P. (2010). Working capital Management in SMEs. Accounting \& Finance, 50(3), 511-527.

Barberis, N., Huang, M., and Santos, T. (2001), "Prospect Theory and Asset Prices", Quarterly Journal of Economics, $116(1), 1-53$.

Benartzi, S., \& Thaler, R. H. (1995). Myopic Loss Aversion and the Equity Premium Puzzle. The Quarterly journal of Economics, 110(1), 73-92.

Bisin, A., Lizzeri, A., \& Yariv, L. (2015). Government Policy with Time Inconsistent Voters. American Economic Review, 105(6), 1711-37.

Birkinshaw, J., Brannen, M. Y., \& Tung, R. L. (2011). From a Distance and Generalizable to up close and Grounded: Reclaiming a Place for Qualitative Methods in International Business Research. Journal of International Business Studies, 42(5),573-581.

Blinder, A. S., \& Maccini, L. J. (1991). Taking Stock: A Critical Assessment of Recent Research on Inventories. Journal of Economic perspectives, 5(1), 73-96.

Bodnaruk, A., \& Simonov, A. (2016). Loss-averse Preferences, Performance, and Career Success of Institutional Investors. The Review of Financial Studies, 29(11), 3140-3176.

Bouteska, A., \& Regaieg, B. (2018). Loss Aversion, Overconfidence of Investors and their impact on Market Performance Evidence from the US Stock Markets. Journal of Economics, Finance and Administrative Science.

Burke, L. A., \& Miller, M. K. (2001). Phone Interviewing as a Means of Data Collection: Lessons learned and practical Recommendations. In Forum Qualitative Sozialforschung/Forum: Qualitative Social Research, 2(2), Art. 7.

Cachia, M., \& Millward, L. (2011). The Telephone Medium and Semi-Structured Interviews: A Complementary fit. Qualitative Research in Organizations and Management: An International Journal. 6(3) 265-277.

Cherono, I., Olweny, T., \& Nasieku, T. (2019). Investor Behavior Biases and Stock Market Reaction in Kenya. Journal of Applied Finance \& Banking, 9(1), 147-180

Creswell, J. W., \& David, J. C. (2018). Research Design: Qualitative, Quantitative, and Mixed Methods Approaches. 4th edition. Los Angeles: SAGE. Publication

Deakin, H., \& Wakefield, K. (2014). Skype Interviewing: Reflections of two PhD Researchers. Qualitative Research, 14(5), 603-616.

Deloof, M., (2003). Does Working Capital Management Affect Profitability of Belgian Firms? Journal of Business, Finance and Accounting 30, 573-587.

Domegan, C., \& Fleming, D. (2007). Marketing research in Ireland: Theory and practice. Gill \& Macmillan.

Donkor, J. (2015). Working Capital Management of SMEs: Ghana's version of the story. Journal of Economics, Management and Trade, 1-12.

Dyer, Jr. W. G., \& Wilkins, A. L. (1991). Better Stories, not Better Constructs, to Generate Better Theory: A Rejoinder to Eisenhardt. Academy of Management Review, 16(3), 613-619.

Etikan, I., Musa, S. A., \& Alkassim, R. S. (2016). Comparison of Convenience Sampling and purposive sampling. American Journal of Theoretical and Applied Statistics, 5(1), 1-4.

Fenig, S., Levav, I., Kohn, R., \& Yelin, N. (1993). Telephone vs face-To-face Interviewing in a community psychiatric Survey. American Journal of Public Health, 83(6), 896-898. 
INTERNATIONAL JOURNAL OF ACADEMIC RESEARCH IN BUSINESS AND SOCIAL SCIENCES

Vol. 10, No. 5, May, 2020, E-ISSN: 2222-6990 C 2020 HRMARS

Filbeck, G., \& Lee, S. (2000). Financial Management Techniques in Family Businesses. Family Business Review, 13(3), 201-216.

Fontana, F., \& Frey, J. (2000). The Interview: From Structured Questions to Negotiated text. In N. K. Denzin \& Y. S. Lincoln (Eds.), Handbook of Qualitative Research (pp. 645-672). Thousand Oaks, CA: Sage

Gal, D., \& Rucker, D. D. (2018). The Loss Aversion: Will it Loom Larger than its Gain? Journal of Consumer Psychology, 28(3), 497-516.

Glogowska, M., Young, P., \& Lockyer, L. (2011). Propriety, Process and Purpose: Considerations of the Use of the Telephone Interview Method in an Educational Research Study. Higher Education, 62(1), 17-26.

Guba, E. G., \& Lincoln, Y. S. (2004). Competing Paradigms in Qualitative Research: Theories and Issues. Approaches to Qualitative Research: A Reader on Theory and Practice, 17-38.

Guba, E., \& Lincoln, Y. (1994). Competing Paradigms in Qualitative Research. In N. Denzin \& Y. Lincoln (Eds.), Handbook of Qualitative Research (P. 105-117). Thousand Oaks, CA: Sage

Hamza, K., Mutala, Z., \& Antwi, S. K. (2015). Cash Management Practices and Financial Performance of Small and Medium Enterprises (SMEs) in the Northern Region of Ghana. International Journal of Economics, Commerce and Management, 3(7), 456-480.

Hsieh, H. H., \& Hodnett, K. (2011). Tests of the Overreaction Hypothesis and the Timing of Mean Reversals on the JSE Securities Exchange (JSE): The Case of South Africa. Journal of Applied Finance \& Banking, 1(1), 107-130.

Kahneman, D., \& Tversky, A. (1979). Prospect Theory: An Analysis of Decision Under Risk. Econometrica, 47, 263-291.

Kelly, T. (2004). Sunk costs, Rationality, and Acting for the Sake of the Past. Noûs, 38(1), 60-85.

Konak, F., \& Güner, E. N. (2016). The Impact of Working Capital Management on Firm Performance: An Empirical Evidence from the BIST SME Industrial index. International Journal of Trade, Economics and Finance, 7(2), 38-43.

Lamptey, L. L., Frimpong, K., \& Morrison, A. B. (2017). Empirical study on the Influence of Working Capital Management on Performance of SMEs in a Developing Economy. Journal of Economics, Management and Trade, 217(4), 1-10.

Lincoln, Y. S., \& Guba, E. G. (1985). Naturalistic Inquiry. Newbury Park, CA: Sage

Locke, P. R., \& Mann, S. C. (2005). Professional Trader Discipline and Trade Disposition. Journal of Financial Economics, 76(2), 401-444.

Mahina, J. N., Muturi, W. M., \& Memba, F. S. (2017). Influence of Loss Aversion Bias on Investments at The Rwanda Stock Exchange.

Merriam, S. B. (2009). Qualitative Case Study Research. Qualitative Research: A Guide to Design and Implementation, 39-54.

Odean, T. (1998). Are investors reluctant to realize their losses? The Journal of finance, 53(5), 17751798.

Pais, M. A., \& Gama, P. M. (2015). Working Capital Management and SMEs Profitability: Portuguese Evidence. International Journal of Managerial Finance, 11 ( 3), 341-358.

Palys, T. (2008). Purposive Sampling. The Sage Encyclopedia of Qualitative Research Methods, 2(1), 697-698. 
INTERNATIONAL JOURNAL OF ACADEMIC RESEARCH IN BUSINESS AND SOCIAL SCIENCES

Vol. 10, No. 5, May, 2020, E-ISSN: 2222-6990 C 2020 HRMARS

Pope, D. G., \& Schweitzer, M. E. (2011). "Is Tiger Woods Loss Averse? Persistent Bias in the Face of Experience, Competition, and High Stakes," American Economic Review, 101(1), 2011, 129157

Rephael, A., Kandel, S., and Wohl, A. (2012), "Measuring Investor Sentiment with Mutual Fund flows", Journal of Financial Economics, 104 (2), 363-382.

Rostami, M., \& Dehaghani, Z. A. (2015). Impact of Behavioral Biases (Overconfidence, Ambiguityaversion and loss-aversion) on Investment Making Decision in Tehran Stock Exchange. Journal of Scientific Research and Development, 2(4), 60-64.

Shelden, D. L., Angell, M. E., Stoner, J. B., \& Roseland, B. D. (2010). School Principals' Influence on Trust: Perspectives of Mothers of Children with Disabilities. The Journal of Educational Research, 103(3), 159-170.

Shiller, R. J. (1998), "Human Behavior and the Efficiency of Financial System", Handbook of Macroeconomics, Vol. 1 No. 20, pp. 1305-1340.

Siggelkow, N. (2007). Persuasion with Case studies. Academy of management journal, 50(1), $20-24$. Spradley, J. (1979). Asking Descriptive Questions. The Ethnographic Interview, 1, 44-61.

Stake, R. (2000). Case studies. In N. K. Denzin \& Y. S. Lincoln (Eds.), Handbook of qualitative research (pp. 435-454). Thousand Oaks, CA: Sage

Strauss, A., \& Corbin, J. (1998). Basics of qualitative Research: Techniques and procedures for Developing Grounded theory. Thousand Oaks, CA: Sage.

Kahneman, D., Knetsch, J. L., \& Thaler, R. H. (2008). The Endowment Effect: Evidence of losses valued more than gains. Handbook of experimental economics results, 1, 939-948.

Trier-Bieniek, A. (2012). Framing the Telephone Interview as a Participant-Centered tool for Qualitative Research: A Methodological Discussion. Qualitative Research, 12(6), 630-644.

Tversky, A., \& Kahneman, D. (1974). Judgment under Uncertainty: Heuristics and Biases, Science, 185(4157), 1124-1131

Tversky, A., \& Kahneman, D. (1984) Judgment under Uncertainty, Heuristic Biases. Science, 185(1), 124-1131.

Williams, A., Harte, D., \& Turner, J. (2015). The value of UK hyperlocal community news: Findings from a content analysis, an online survey and interviews with producers. Digital Journalism, 3(5), 680-703.

Vogl, S. (2013). Telephone Versus Face-to-face Interviews: Mode Effect on Semi structured interviews with children. Sociological Methodology, 43(1), 133-177

Yin R. K. (2003). Case Study Research: Design and Methods. Third Edition. SAGE Publications, London.

Yin, R. K. (1994). Discovering the Future of the Case Study. Method in Evaluation Research. Evaluation Practice, 15(3), 283-290. 